\title{
BENTUK KLAUSULA-KLAUSULA BAKU DALAM PERJANJIAN KREDIT BANK
}

\author{
Marsidah \\ Fakultas Hukum Universitas Palembang \\ E-mail:marsidahelan@gmail.com
}

\begin{abstract}
Every bank loan must be stated in a written credit agreement. Bank credit agreement is a standard agreement with the contents or clauses of the bank credit agreement that has been standardized and set forth in the form of a form (blank), but not bound in a certain form. The validity of the credit agreement lies in public acceptance and business traffic to facilitate standard agreements in general is an unequal clause between the creditors (banks) and debtors (customers) which causes the principle of balance in the agreement as if not fulfilled. Based on the foregoing, the formulation of the problem in this paper is What are the standard clauses in a bank credit agreement. While the purpose of this paper is to describe, know and understand the forms of standard clauses in bank credit agreements. In connection with the problem under study are the forms of standard clauses in bank credit agreements including credit facilities, interest rates, bank power, bank repayment guarantees, precedent loans, credit collateral, affirmative and negative covenants, bank actions in saving loans, event of default, legal choice, start the entry into force of the credit agreement.
\end{abstract}

Keywords: Credit Agreement; Bank Credit

\begin{abstract}
Abstrak
Setiap pemberian kredit bank harus dituangkan dalam perjanjian kredit secara tertulis. Perjanjian kredit bank merupakan perjanjian baku dengan isi atau klausula perjanjian kredit bank tersebut telah dibakukan dan dituangkan dalam bentuk formulir (blanko), tetapi tidak terikat dalam suatu bentuk tertentu. Keabsahan perjanjian kredit terletak pada penerimaan masyarakat dan lalu lintas bisnis untuk memperlancar perjanjian baku pada umumnya merupakan klausula yang tidak setara antara pihak kreditur (bank) dan debitur (nasabah) yang menyebabkan prinsip kesimbangan dalam perjanjian seolah-olah tak terpenuhi. Berdasarkan hal tersebut di atas, maka rumusan masalah dalam penulisan ini adalah Bagaimanakah bentuk klausula-klausula baku dalam perjanjian kredit bank. Sedangkan tujuan dari penulisan ini adalah untuk menguraikan, mengetahui dan memahami bentuk-bentuk klausula baku dalam perjanjian kredit bank. Sehubungan dengan permasalahan yang diteliti adalah bentuk-bentuk klausula-klausula baku dalam perjanjian kredit bank meliputi fasilitas kredit, suku bunga, kuasa bank, jaminan pelunasan bank, kredit precedent, agunan kredit, affirmative dan negative covenant, tindakan bank dalam penyelamatan kredit, event of default/wanprestasi, pilihan hukum, mulai berlakunya perjanjian kredit.
\end{abstract}

Kata Kunci: Perjanjian Kredit; Kredit Bank

\section{PENDAHULUAN}

Bank daam pembicaraan sehari-hari dikenal sebagai lembaga keuangan yang kegiatan utamanya menerima simpanan giro, tabungan dan deposito. Bank juga dikenal sebagai tempat untuk meminjam uang (kredit) bagi masyarakat yang membutuhkannya, selain itu juga sebagai tempat untuk menukar uang, memindahkan uang atau menerima segala macam bentuk pembayaran dan setoran seperti pembayaran listrik, air, 
Marsidah, Bentuk Klausula-Kalusula Baku dalam Perjanjian Kredit Bank, Halaman 285-302

telepon, pajak, uang kuliah dan pembayaran lainnya.

Perbankan, khususnya bank umum merupakan inti dari sistem keuangan setiap negara. Bank merupakan lembaga keuangan yang menjadi tempat bagi perusahaan, badan-badan pemerintah dan swasta, maupun perorangan menyimpan dana-dananya. Melalui kegiatan perkreditan dan berbagai jasa yang diberikan, bank melayani kebutuhan pembiayaan serta melancarkan mekanisme sistem pembayaran bagi semua sektor perekonomian.

Pengertian bank secara konkrit di dalam beberapa buku, hanya berupa istilah-istilah seperti yang diungkapkan oleh Abdurrachman. Bank berasal dari bahasa Itali yaitu "banca" yang berarti suatu bangku tempat duduk, sebab pada zaman pertengahan, pihak banker yang memberikan pinjaman-pinjaman melakukan usahanya tersebut dengan duduk di bangku-bangku di halaman pasar. $^{1}$

\section{Menurut Black Henry Campbell,} seperti yang dikutip oleh Hermansyah, memberi arti kepada bank sebagai suatu

1 Abdurrachman, Ensiklopedia Ekonomi Keuangan Perdagangan, Jakarta: Pradnya Paramita, 1991, hlm. 43. institusi yang mempunyai peran besar dalam dunia komersil yang mempunyai wewenang untuk menerima deposito, memberi pinjaman, menerbitkan promissory notes yang sering disebut dengan bank bills atau bank notes. Namun demikian, fungsi bank yang original adalah hanya menerima deposito berupa uang logam, plate, emas, dan lain-lain.

Pengertian Bank dalam Pasal 1 angka 1 Undang-Undang Perbankan Nomor 10 Tahun 1998, lengkapnya sebagai berikut :"Bank adalah Badan Usaha yang menghimpun dana dari masyarakat dalam bentuk simpanan, dan menyalurkan kepada masyarakat dalam bentuk kredit dan/atau bentuk-bentuk lainnya dalam rangka meningkatkan taraf hidup rakyat banyak."

Lembaga perbankan sebagai salah satu lembaga keuangan mempunyai nilai strategis dalam kehidupan perekonomian suatu negara. Lembaga tersebut dimaksudkan sebagai perantara pihak-pihak yang mempunyai kelebihan dana (surplus of funds) dengan pihak-pihak yang kekurangan dan memerlukan dana (lack of funds).

2 Gatot Supramono, Perbankan dan Masalah Kredit: Suatu Tinjauan Yuridis, Djambatan, Jakarta: Rineka Cipta, 2009, hlm. 1. 
Marsidah, Bentuk Klausula-Kalusula Baku dalam Perjanjian Kredit Bank, Halaman 285-302

Perbankan akan bergerak dalam kegiatan perkreditan dan berbagai jasa yang diberikan bank melayani kebutuhan pembiayaan serta melancarkan mekanisme sistem pembayaran bagi semua faktor perekonomian.

Perbankan sebagai lembaga internasional intermediasi keuangan (financial intermediary institution) memegang peranan penting dalam proses pembangunan nasional. Kegiatan usaha utama bank menurut Undang-Undang Perbankan Pasal 1 ayat 2, berupa menghimpun dana dari masyarakat dalam bentuk simpanan dan menyalurkannya kembali kepada masyarakat dalam bentuk kredit dan/atau pembiayaan membuatnya sarat akan pengaturan baik melalui peraturan perundang-undangan di bidang perbankan sendiri maupun perundang-undangan lain yang terkait.

Pemberian kredit adalah merupakan pelayanan yang nyata dari bank dalam kehidupan serta pengembangan perekonomian di Indonesia. Kredit adalah penyediaan uang atau tagihan yang dapat dipersamakan dengan itu, berdasarkan persetujuan atau kesepakatan pinjam-memintam antara bank dengan pihak lain yang mewajibkan pihak peminjam untuk melunasi utangnya setelah jangka waktu tertentu dengan pemberian bunga. ${ }^{3} \mathrm{Hal}$ ini sesuai dengan pernyataan yang menyatakan bahwa Bank adalah badan usaha yang menghimpun dana dari masyarakat dalam bentuk simpanan dan menyalurkannya kepada masyarakat dalam bentuk kredit dan/atau bentuk-bentuk lainnya yang dipersamakan dengan itu dalam rangka meningkatkan taraf hidup rakyat banyak. 4 Berdasarkan ketentuan undang-undang tersebut maka dapat dilihat bahwa fungsi pokok dari perbankan, adalah menghimpun dana dari masyarakat dalam bentuk simpanan dan menyalurkan dana yang telah dihimpun tersebut kembali pada masyarakat yang memerlukannya dengan bentuk kredit.

Dalam pelaksanaan pemberian kredit tersebut, tentunya para pihak perlu mentaati suatu perjanjian kredit yang berbentuk klausula baku yang telah dibuat oleh pihak bank itu sendiri. Menurut Pasal 1313 KUH Perdata, perjanjian adalah perbuatan dengan mana satu orang atau lebih mengikatkan dirinya terhadap satu orang lain atau

${ }^{3}$ Undang-Undang Nomor 10 Tahun 1998 Pasal 1 Butir 11 tentang Perubahan atas Undang-Undang Nomor 7 Tahun 1992 tentang Perbankan ${ }^{4}$ Ibid 
Marsidah, Bentuk Klausula-Kalusula Baku dalam Perjanjian Kredit Bank, Halaman 285-302

lebih. Sedangkan klausula baku adalah setiap aturan atau ketentuan dan syarat-syarat yang telah dipersiapkan dan ditetapkan terlebih dahulu secara sepihak oleh pelaku usaha yang dituangkan dalam suatu dokumen dan/atau perjanjian yang mengikat dan wajib dipenuhi oleh konsumen. ${ }^{5}$

Perjanjian kredit bank dalam kegiatan perbankan merupakan perjanjian standar yang sudah dibuat oleh pihak bank walaupun pada dasarnya tidak setara bagi pihak debitur atau konsumen. Berdasarkan dengan uraian terdahulu maka perlu pemahaman yang mendalam terhadap pentingnya klausula buku dalam perjanjian kredit bank. Oleh karena itu,dapat dirumuskan permasalahan pada bagaimanakah bentuk klausula-klausula baku dalam perjanjian kredit bank. Sehingga tujuan dari penulisan ini adalah untuk menguraikan, mengetahui dan memahami bentuk-bentuk klausula-klausula dalam perjanjian kredit bank.

\section{PEMBAHASAN}

\section{A. Pengertian Perjanjian}

\footnotetext{
5 Undang-Undang Nomor 8 Tahun 1999 tentang Perlindungan Konsumen
}

Pengertian perjanjian diatur di dalam Bab II Buku III Kitab Undang-Undang Hukum Perdata tentang "Perikatan-perikatan yang dilahirkan dari kontrak atau perjanjian", mulai Pasal 1313 sampai dengan Pasal 1351, dimana ketentuan dalam Pasal 1313 merumuskan pengertian perjanjian yang berbunyi : "Suatu perjanjian adalah suatu perbuatan dengan mana satu orang atau lebih mengikatkan dirinya terhadap satu orang lain atau lebih."

Perjanjian adalah persetujuan yang dapat dibuat secara lisan atau tertulis antara dua orang atau lebih kepada satu orang lain atau lebih yang masing-masing pihak berjanji atau menaati apa yang tersebut dalam persetujuan. Perjanjian ini didasarkan kata sepakat yang dapat menimbulkan perbuatan dan akibat hukum dalam melaksanakan hak dan kewajiban. Satu pihak adalah yang wajib berprestasi dan pihak lainnya adalah yang berhak atas prestasi tersebut, ada hubungan timbal-balik dari dua pihak.

Ketentuan hukum yang mengatur tentang syarat-syarat yang harus dipenuhi dalam perjanjian sehingga perjanjian berlaku secara sah adalah Pasal 1320 KUH Perdata yang terdiri atas : 
Marsidah, Bentuk Klausula-Kalusula Baku dalam Perjanjian Kredit Bank, Halaman 285-302

1. Adanya Kesepakatan Kedua Belah Pihak

Kesepakatan merupakan kesesuaian kehendak mereka yang mengikatkan diri. Kata sepakat muncul dari kemauan bebas dari para pihak yang dinyatakan dalam isi perjanjian. Pernyataan tersebut dapat dinyatakan secara tegas baik lisan maupun tulisan.

2. Adanya Kecakapan Dari Pihak-Pihak Untuk Membuat Perikatan

Sesuai Pasal 1329 KUH Perdata, "Setiap orang adalah cakap membuat perikatan-perikatan jika ia oleh undang-undang tidak dinyatakan tidak cakap. Seseorang dikatakan cakap hukum apabila laki-laki atau wanita yang telah berumur 21 tahun atau belum berumur 21 tahun tetapi telah menikah. Pasal 1330 KUH Perdata menyebutkan orang-orang yang tidak cakap membuat perjanjian, yaitu :

a) Orang-orang yang belum dewasa.

b) Mereka yang ditaruh di bawah pengampuan.

c) Orang-orang perempuan, dalam hal ini telah ditetapkan undang-undang (telah dicabut dengan Surat Edaran Mahkamah Agung Nomor 3 Tahun 1963).

\section{Adanya Suatu Hal Tertentu}

Suatu hal tertentu menyangkut obyek umum perjanjian atau mengenai bendanya. Obyek perjanjian harus jelas, syarat ini diperlukan untuk menentukan hak dan kewajiban para pihak jika terjadi perselisihan.

\section{Adanya Suatu Sebab yang Tidak} Dilarang Oleh Undang-Undang

Sebab yang halal berkaitan dengan isi perjanjian, apakah isi perjanjian dilarang oleh undang-undang, bertentangan dengan ketertiban umum, kepatutan dan kesusilaan seperti yang tercantum dalam Pasal 1337 KUH Perdata. Menentukan suatu sebab yang halal adalah apabila tidak bertentangan dengan Undang-undang, tidak bertentangan dengan ketertiban umum dan kesusilaan. ${ }^{6}$

Syarat pertama dan kedua adalah mengenai subyek atau pihak dalam perjanjian yang disebut syarat subyektif, sedangkan syarat ketiga dan keempat adalah mengenai obyek perjanjian yang disebut syarat obyektif. Apabila syarat

${ }^{6}$ Sri Soedewi Masjachan, Hukum Jaminan di Indonesia Pokok-Pokok Hukum Jaminan dan Jaminan Perorangan, Yogyakarta: Liberty, 1980, hlm. 139. 
Marsidah, Bentuk Klausula-Kalusula Baku dalam Perjanjian Kredit Bank, Halaman 285-302

subyektif tidak dipenuhi, maka salah satu pihak mempunyai hak untuk meminta agar perjanjian itu dibatalkan. Pihak yang meminta pembatalan adalah pihak yang tidak cakap atau memberikan sepakatnya dalam keadaan tidak bebas. Jadi perjanjian yang dibuat tetap mengikat para pihak selama tidak dibatalkan oleh hakim atas permintaan pihak yang meminta pembatalan. Apabila syarat objektif tidak dipenuhi, maka perjanjian itu batal demi hukum, artinya sejak semula tidak pernah dilahirkan suatu perjanjian dan tidak pernah ada suatu perikatan. Tujuan para pihak yang mengadakan perjanjian untuk melahirkan suatu perikatan hukum adalah gagal, sehingga tidak ada dasar hukum untuk saling menuntut di depan hakim.

Perjanjian kredit bank melibatkan dua pihak yaitu nasabah sebagai pemohon kredit (debitur) dan pihak bank sebagai pemberi kredit (kreditur).

Thomas Suyatno, et.al. mengemukakan bahwa kredit bank yang semula mengandalkan kredit likuiditas Bank Indonesia, secara bertahap dialihkan menjadi penyediaan kredit biasa oleh perbankan dan lembaga-lembaga keuangan lain yang didasarkan atas dana yang dihimpun dari masyarakat. ${ }^{7}$

Sedangkan M. Djumhana dalam bukunya Hukum Perbankan di Indonesia, mengemukakan bahwa : "Berjalannya kegiatan perkreditan akan lancar apabila adanya saling mempercayai dari semua pihak yang terkait dalam kegiatan tersebut. Kegiatan itupun dapat terwujud hanyalah apabila semua pihak terkait mempunyai integritas moral." $"$

\section{B. Pengertian Perjanjian Kredit}

Tujuan pemberian kredit adalah untuk memenuhi kebutuhan yang beraneka ragam sesuai dengan uzharkatnya, yang selalu meningkat. Sedangkan kemampuan manusia mempunyai suatu batasan tertentu memaksakan seseorang untuk berusaha memperoleh bantuan permodalan untuk pemenuhan hasrat dan cita-citanya guna peningkatan usaha dan peningkatan daya guna sesuatu barang/jasa. Fungsi kredit perbankan dalam kehidupan perekonomian dan perdagangan antara lain sebagai berikut:

7 Thomas Suyatno, Dasar-Dasar Perkreditan, Jakarta: Gramedia, 1990, hlm. 27.

${ }^{8}$ Muhammad Djumhana, Hukum Perbankan di Indonesia, Bandung: PT. Citra Aditya Bakti, 2006, hlm. 55. 
Marsidah, Bentuk Klausula-Kalusula Baku dalam Perjanjian Kredit Bank, Halaman 285-302

Fungsi kredit perbankan dalam kehidupan perekonomian dan perdagangan antara lain sebagai berikut:

\section{a. Kredit Dapat Meningkatkan}

\section{Daya Guna Uang}

1) Para pemilik uang atau modal dapat secara langsung meminjamkan uangnya kepada para pengusaha yang memerlukannya, untuk meningkatkan produksi atau untuk meningkatkan usahanya.

2) Para pemilik uang/modal dapat menyimpan uangnya pada lembaga-lembaga keuangan. Uang tersebut diberikan sebagai pinjaman kepada perusahaan-perusahaan untuk meningkatkan usahanya.

\section{b. Kredit Dapat Meningkatkan Peredaran dan Lalu Lintas Uang}

Kredit uang yang disalurkan melalui rekening giro dapat menciptakan pembayaran baru seperti cek, giro bilyet, dan wesel maka akan dapat meningkatkan peredaran uang giral. Para pengusaha dapat memproses bahan baku menjadi barang jadi, sehingga daya guna barang tersebut menjadi meningkat, apabila para pengusaha tersebut mendapatkan kredit.

c. Kredit Sebagai Salah Satu Alat Stabilitas Ekonomi

Dalam keadaan ekonomi yang kurang sehat, kebijakan diarahkan pada usaha-usaha antara lain: pengendalian inflasi; peningkatan ekspor, dan pemenuhan kebutuhan pokok rakyat.

\section{d. Kredit Dapat Meningkatkan}

\section{Kegairahan Berusaha}

Bantuan kredit yang diberikan oleh bank akan dapat mengatasi kekurang mampuan para pengusaha di bidang permodalan tersebut sehingga para pengusaha akan dapat meningkatkan usahanya.

\section{e. Kredit Dapat Meningkatkan}

\section{Penerimaan Pendapatan}

Dengan bantuan kredit dari bank, para pengusaha dapat memperluas usahanya dan mendirikan proyek-proyek baru.

\section{f. Kredit Sebagai Alat Untuk Meningkatkan Hubungan Internasional}


Marsidah, Bentuk Klausula-Kalusula Baku dalam Perjanjian Kredit Bank, Halaman 285-302

Bank-bank di luar negeri yang mempunyai jaringan usaha, dapat memberikan bantuan dalam bentuk kredit, baik secara langsung maupun tidak langsung kepada perusahaan-perusahaan di dalam negeri. Bantuan dalam bentuk ini tidak saja dapat mempererat hubungan ekonomi antar negara yang bersangkutan tetapi juga dapat meningkatkan hubungan internasional.

Prinsip-prinsip Pemberian Kredit, bank dalam menentukan nilai kredit dikenal adanya prinsip "5-C" yaitu : 9

\section{a. Character}

Bank mencari data tentang sifat-sifat pribadi, watak dan kejujuran dari pimpinan perusahaan dalam memenuhi kewajiban finansialnya. Beberapa petunjuk bagi bank untuk mengetahui karakter nasabah adalah : Mengenal dari dekat, mengumpulkan keterangan dari aktivitas calon debitur dalam perbankan, mengumpulkan keterangan dan minta pendapat dari rekan-rekannya, pegawai, dan saingannya mengenai reputasi, kebiasaan pribadi, pergaulan sosial dan lain-lain.

\section{b. Capacity}

Menyangkut kemampuan perusahaan beserta stafnya baik

9 Permadi Gandapradja, Dasar dan Prinsip Pengawasan Bank, Jakarta: PT. Gramedia Pustaka Utama, 2004, hlm. 23. kemampuan dalam manajemen maupun keahlian dalam bidang usahanya.

\section{c. Capital}

Ini menunjukkan posisi finansiil perusahaan secara keseluruhan yang ditunjukkan oleh ratio finansiilnya dan penekanan pada komposisi "tangible network-nya". Bank harus mengetahui bagaimana pertimbangan antara jumlah hutang dengan jumlah modal sendiri.

\section{d. Collateral}

Collateral berarti jaminan. Ini menunjukkan besarnya aktiva yang akan diikatkan sebagai jaminan atas kredit yang diberikan oleh bank.

\section{e. Condition of Economy}

Bank harus melihat kondisi ekonomi secara umum, serta kondisi pada sektor usaha debitur. Bank harus memperhatikan keadaan ekonomi yang akan mempengaruhi perkembangan usaha calon debitur.

Bank dalam memberikan kredit, selain menerapkan prinsip 5-C's, juga menerapkan apa yang dinamakan dengan prinsip $5 \mathrm{P}$, yaitu : ${ }^{10}$

\section{a. Party (Para Pihak)}

Para pihak merupakan titik sentral yang diperhatikan dalam setiap pemberian kredit, untuk itu

10 Rachmat Firdaus dan Maya Ariyanti, Manajemen Perkreditan Bank Umum, Jakarta: Alfabeta, 2011, hlm. 88. 
Marsidah, Bentuk Klausula-Kalusula Baku dalam Perjanjian Kredit Bank, Halaman 285-302

pihak pemberi kredit harus memperoleh suatu "kepercayaan" terhadap para pihak, dalam hal ini debitur. Bagaimana karakternya, kemampuannya, dan sebagainya.

\section{b. Purpose (Tujuan)}

Tujuan dari pemberian kredit juga sangat penting diketahui oleh pihak kreditur. Harus dilihat apakah kredit akan digunakan untuk hal-hal yang positif, yang benar-benar menaikkan income perusahaan, dan harus pula diawasi agar kredit tersebut benar-benar diperuntukkan untuk tujuan seperti diperjanjikan dalam suatu perjanjian kredit.

\section{c. Payment (Pembayaran)}

Diperhatikan pula apakah sumber pembayaran kredit dari calon debitur cukup tersedia dan cukup aman, sehingga dengan demikian diharapkan bahwa kredit yang akan diluncurkan tersebut dapat dibayar kembali oleh debitur yang bersangkutan. Bank harus melihat dan menganalisis, apakah setelah pemberian kredit nanti, debitur punya sumber pendapatan, dan apakah pendapatan tersebut mencukupi untuk membayar kembali kreditnya.

\section{d. Profitability (Perolehan Laba)}

Unsur perolehan laba oleh debitur tidak kurang pada pentingnya dalam suatu pemberian kredit. Untuk itu, kreditur harus berantisipasi apakah laba yang akan diperoleh oleh perusahaan lebih besar daripada bunga pinjaman, dan apakah pendapatan perusahaan dapat menutupi pembayaran kembali kredit, cash flow, dan sebagainya.

\section{e. Protection (Perlindungan)}

Unsur perolehan laba oleh debitur tidak kurang pula pentingnya dalam suatu pemberian kredit. Untuk itu, kreditur harus berantisipasi apakah laba yang akan diperoleh oleh perusahaan lebih besar daripada bunga pinjaman, dan apakah pendapatan perusahaan dapat menutupi pembayaran kembali kredit, cash flow, dan sebagainya.

Disamping menggunakan prinsip pemberian kredit di atas, bank dalam memberikan kredit juga menggunakan prinsip 3R, yaitu : ${ }^{11}$

\section{a.Return (Hasil yang Diperoleh)}

Return, yakni hasil yang diperoleh debitur, dalam hal ini ketika kredit telah dimanfaatkan dan dapat diantisipasi oleh calon kreditur, artinya perolehan tersebut mencukupi untuk membayar kembali kredit beserta bunga, biaya-biaya, di samping membayar keperluan perusahaan yang lain seperti untuk cash flow, kredit lain jika ada dan sebagainya.

b. Repayment Kembali)

(Pembayaran

Kemampuan dari pihak debitur tentu saja juga harus dipertimbangkan, dan apakah kemampuan bayar tersebut match

\footnotetext{
11 Ismail, Manajemen Perbankan, Jakarta: Kencana, 2011, hlm. 116.
} 
Marsidah, Bentuk Klausula-Kalusula Baku dalam Perjanjian Kredit Bank, Halaman 285-302

dengan schedule pembayaran kembali dari kredit yang akan diberikan itu. Ini juga merupakan hal yang tidak boleh diabaikan.

\section{c. Risk Bearing Ability (Kemampuan Menanggung Risiko)}

Hal lain yang perlu diperhatikan adalah sejauh mana terdapatnya kemampuan debitur untuk menanggung risiko, misalnya dalam hal terjadi sesuatu di luar antisipasi kedua belah pihak, terutama jika dapat menyebabkan timbulnya kredit macet. Untuk itu, harus diperhitungkan apakah misalnya jaminan dan/atau asuransi barang atau kredit sudah cukup aman untuk menutupi risiko tersebut.

Mariam Darus Badrulzaman mengatakan bahwa perjanjian kredit adalah perjanjian pendahuluan yang bersifat konsensuil sedangkan penyerah uangnya bersifat riil. Dalam aspek konsensuil dan riil perjanjian kredit memiliki identitas sendiri dengan sifat-sifat umum sebagai berikut $:^{12}$

1. Merupakan perjanjian pendahuluan (voorovereenkomst) dari perjanjian penyerahan uang;

2. Perjanjian kredit bersifat konsensuil;

3. Perjanjian penyerahan uangnya bersifat riil;

4. Perjanjian kredit termasuk dalam jenis perjanjian standar;

12 Mariam Darus Badrulzaman, Perjanjian Kredit Bank, Bandung: Alumni, 1996, hlm. 179.
5. Perjanjian kredit banyak dicampuri pemerintah;

6. Perjanjian kredit lazimnya dibuat secara rekening Koran;

7. Perjanjian kredit harus mengandung perjanjian jaminan;

8. Perjanjian kredit dalam aspek riil adalah perjanjian sepihak;

9. Perjanjian kredit dalam aspek konsensuil adalah perjanjian timbal balik.

Remy Sjahdeini mengemukakan bahwa perjanjian kredit tidak identik dengan perjanjian pinjam uang dalam KUH Perdata. Ada ciri khusus dari perjanjian kredit yang membedakannya dari perjanjian pinjam uang biasa. Ciri khusus tersebut adalah ada beberapa bank yang memuat dalam perjanjian kreditnya klausul yang dinamakan condition precedent yakni peristiwa atau kejadian yang harus dipenuhi atau terjadi terlebih dahulu setelah perjanjian ditandatangani oleh para pihak sebelum penerima kredit dapat menggunakan kreditnya. Perjanjian yang mengandung condition precedent adalah perjanjian konsensuil dan bukan perjanjian riil, sedangkan perjanjian kredit yang tidak memuat condition precedent dikatakan perjanjian riil. ${ }^{13}$

\footnotetext{
13 Remy Sjahdeini, Perbankan Islam dan
} Kedudukannya Dalam Tata Hukum Perbankan 
Marsidah, Bentuk Klausula-Kalusula Baku dalam Perjanjian Kredit Bank, Halaman 285-302

Dari rumusan tersebut dapat diketahui, bahwa kredit itu merupakan perjanjian pinjam-meminjam uang antara bank sebagai kreditur dengan nasabah sebagai debitur. Bank sebagai pemberi kredit percaya terhadap nasabahnya dalam jangka waktu yang disepakatinya akan dikembalikan (dibayar) lunas. Tenggang waktu antara pemberian dan penerimaan kembali prestasi ini menurut Mgs. Edy Putra The Aman, 14 merupakan suatu hal yang abstrak, yang sukar diraba, karena masa antara pemberian dan penerimaan prestasi tersebut dapat berjalan beberapa bulan, tetapi dapat pula berjalan beberapa tahun.

Hal tersebut memang dapat terjadi, karena dalam praktek banyak terjadi nasabah tidak menepati waktu yang diperjanjikan dalam mengembalikan pinjamannya dengan berbagai alasan. Oleh karena itu, dalam rumusan pengertian kredit ditegaskan mengenai kewajiban nasabah untuk melunasi utangnya sesuai dengan jangka waktunya dan disertai dengan kewajibannya yang lain yaitu dapat

Indonesia, Jakarta: PT. Pustaka Utama Grafity, 1999, hlm. 58.

14 Mgs. Edy Putra The' Aman, Kredit Perbankan Suatu Tinjauan Yuridis, Yogyakarta: Liberty, 2008, hlm. 10. berupa bunga, imbalan atau pembagian hasil keuntungan.

Sebagaimana diketahui bahwa unsur esensial dari kredit bank adalah adanya kepercayaan dari bank sebagai kreditur terhadap nasabah peminjam sebagai debitur. Kepercayaan tersebut timbul karena dipenuhinya segala ketentuan dan persyaratan untuk memperoleh kredit bank oleh debitur antara lain: jelasnya tujuan peruntukkan kredit, adanya benda jaminan atau agunan, dan lain-lain.

Makna dari kepercayaan tersebut adalah adanya keyakinan dari bank sebagai kreditur bahwa kredit yang diberikan akan sungguh-sungguh diterima kembali dalam jangka waktu tertentu sesuai kesepakatan.

Namun perjanjian kredit tersebut tidak selamanya terpenuhi sesuai dengan persyaratan yang telah ditentukan, sehingga hal tersebut menyebabkan kredit macet. Kredit macet dapat disebabkan oleh beberapa faktor, yaitu faktor yang berasal dari nasabah, faktor yang berasal dari bank dan faktor lainnya. Sebagai kreditur tidak terlepas dari kelemahan yang dimiliki. Faktor ini tidak berdiri sendiri, tetapi selalu berkaitan dengan nasabah.

\section{Faktor yang Berasal dari Nasabah}


Marsidah, Bentuk Klausula-Kalusula Baku dalam Perjanjian Kredit Bank, Halaman 285-302

a. Nasabah Menyalahgunakan Kredit

Setiap kredit yang diperoleh nasabah telah diperjanjikan dalam perjanjian kredit tentang tujuan pemakaian kreditnya. Dengan telah diperjanjikan demikian, maka nasabah setelah menerima kredit wajib mempergunakan sesuai dengan tujuannya tersebut. Pemakaian kredit yang menyimpang dari pemakaiannya akan menghasilkan nasabah yang tidak mengembalikan kredit sebagaimana mestinya. Sebagai contoh nasabah diberi kredit untuk kepentingan pengangkutan karena usahanya di bidang angkutan bus luar kota, tetapi nasabah menggunakan kredit untuk kepentingan pertanian dengan membeli bibit bawang merah. Ketika gagal panen nasabah tidak dapat membayar pelunasan kredit.

\section{b. Nasabah Kurang Mampu Mengelola Usahanya}

Nasabah yang telah menerima fasilitas kredit, ternyata dalam praktek tidak mengelola usaha yang dibiayai dengan kredit bank. Nasabah tidak profesional dalam melakukan pekerjaan karena kurang menguasai secara teknis usaha yang dijalankan.
Akibatnya, hasil kerja kurang maksimal dan kurang berkualitas sehingga mempengaruhi minat masyarakat dalam mengonsumsi produk yang dihasilkannya. Keadaan ini mempengaruhi penghasilan nasabah, sehingga berpengaruh pula terhadap kelancaran pelunasan kreditnya.

\section{c. Nasabah Beritikad Tidak Baik}

Ada sebagian nasabah yang mungkin tidak banyak yang sengaja dengan segala daya upaya mendapatkan kredit dari bank, namun setelah kredit diperoleh digunakan begitu saja tanpa dapat dipertanggung jawabkan. Nasabah semacam ini sejak awal memang sudah tidak beritikad baik, karena tujuannya jahat yaitu untuk membobol bank. Biasanya sebelum kredit jatuh tempo nasabah sudah melarikan diri.

\section{Faktor yang Berasal dari Bank}

Bank juga dapat sebagai salah satu penyebab terjadinya kredit macet. Dalam memberikan kredit kepada nasabah, bank selalu membuat pertimbangan atau analisis yang telah ditetapkan Undang-Undang Perbankan. Tidak akuratnya pertimbangan bank akan menjadikan 
Marsidah, Bentuk Klausula-Kalusula Baku dalam Perjanjian Kredit Bank, Halaman 285-302

kredit yang diberikan nasabahnya akan berjalan tidak sesuai dengan yang diharapkan.

\section{a. Kualitas Pejabat Bank}

Setiap petugas atau pejabat bank manapun dituntut untuk melaksanakan pekerjaannya secara profesional sehingga dapat tercipta pelayanan terhadap masyarakat yang memadai. Meskipun demikian tidak semua pejabat bank mempunyai kualitas seperti yang diharapkan. Pejabat bank yang kurang profesional tentu sulit diharapkan dapat memperoleh hasil kerja $\mathrm{y}$ ang maksimal. Terutama pejabat di bagian kredit, kualitasnya dapat mempengaruhi keputusan penyaluran kredit yang tidak sebagaimana mestinya.

\section{b. Persaingan Antar Bank}

Jumlah bank yang makin hari makin banyak merupakan hal yang wajar dengan jumlah penduduk yang bertambah mempengaruhi jumlah kebutuhan terhadap bank bertambah pula. Dengan bertambahnya jumlah bank maka akan mempengaruhi persaingan bank yang semakin ketat.

Dalam melakukan persaingan usaha, setiap bank selain berusaha untuk memberikan pelayanan yang terbaik kepada masyarakat, termasuk kemudahan di dalam memberikan fasilitas kredit. Dengan pelayanan yang terbaik yang bertujuan untuk mendapatkan nasabah sebanyak-banyaknya dan nasabah yang telah ada tetap digandeng agar tidak pindah ke bank lain.

Dengan adanya persaingan usaha yang ketat, akan mempengaruhi bank untuk bertindak spekulatif dengan cara memberikan fasilitas yang mudah kepada nasabah, tetapi di lain pihak langkah yang diambil bank telah mengabaikan prinsip-prinsip perbankan yang sehat.

\section{c. Hubungan Intern Bank}

Kredit macet juga dapat terjadi karena bank terlalu memperhatikan hubungan ke dalam bank, penyaluran kredit tidak merata dan lebih cenderung diberikan kepada pengurus dan pengawas serta pegawai bank. Seperti dikatakan J.B. Sumarlin ketika menjadi Menteri Keuangan, bahwa pada tahun 1992 kredit macet yang terjadi di bank pemerintah karena pemilik bank menikmati fasilitas kredit yang melampaui batas yang ditentukan (batas maksimum pemberian kredit).

Disamping itu juga bank lebih mengutamakan hubungan dengan perusahaan-perusahaan yang masih dalam kelompoknya (induk perusahaan, anak perusahaan) dalam pemberian kredit. Ibarat kelompok perusahaan itu sebuah keluarga, bank merasa terikat dengan sanak keluarganya. Secara yuridis masing-masing perusahaan dalam sebuah kelompok berdiri sendiri-sendiri, namun dari segi ekonomi mereka adalah satu kesatuan. Akibatnya apabila kreditnya bermasalah berpengaruh kepada bank yang kurang berani bertindak tegas.

\section{d. Pengawasan Bank}

Mulai dari proses pemberian kredit, terjadinya perjanjian kredit sampai dengan pelaksanaan perjanjian kredit selalu mendapat pengawasan. Pekerjaan bank diawasi oleh pengawas intern bank dan pengawas ekstern bank yaitu BI dan BPKP khusus untuk bank milik negara. Adanya bank yang tidak sehat atau bahkan bank yang terkena likuiditas tidak dapat dilepaskan dari kredit macet sebagai 
Marsidah, Bentuk Klausula-Kalusula Baku dalam Perjanjian Kredit Bank, Halaman 285-302

penyebabnya. Salah satu faktor terjadinya kredit macet adalah karena lemahnya pengawasan terhadap bank. ${ }^{15}$

\section{Faktor Lainnya}

\section{a. Debitur Meninggal Dunia}

Dalam hal ini, apabila debitur meninggal dunia maka seluruh pinjamannyaaa akan di cover $100 \%$ oleh pihak penjamin dan dianggap lunas atau akan tetap dilakukan penagihan secara terus-menerus kepada ahli waris sampai kredit tersebut lunas, tergantung pada jenis kredit yang diberikan kepada debitur tersebut.

\section{b. Force Majeure}

Adanya keadaan memaksa atau peristiwa yang tidak terduga yang menimbulkan resiko kemacetan. Keadaan ini terjadi akibat adanya bencana alam, kebakaran, perampokan dan lainnya.

c. Kondisi Perekonomian Negara yang Tidak Mendukung Perkembangan Iklim Usaha, misalnya krisis moneter. ${ }^{16}$

Menyangkut tentang keadaan yang menimpa debitur atau nasabah itu dapat diakibatkan oleh keadaan diluar kemampuannya, sehingga ke semua faktor tersebut mengakibatkan keterlambatan debitur untuk

15 Gatot Supramono, Perbankan dan Masalah Kredit Suatu Tinjauan di Bidang Yuridis, Jakarta: Rineka Cipta, 2009, hlm. 268-272.

16 Ade Arthesa dan Edia Handiman, Bank dan Lembaga Keuangan Bukan Bank, Jakarta: PT. Indeks, 2006, hlm. 182-187. mengembalikan kredit yang diberikan oleh bank.

\section{Bentuk Klausula-Klausula Baku}

\section{Dalam Perjanjian Kredit Bank}

Perjanjian kredit merupakan perjanjian baku dimana isi atau klausula perjanjian tersebut telah dibakukan dan dituangkan dalam bentuk formulir (blanko), tetapi tidak terikat dalam suatu bentuk tertentu. Keabsahan perjanjian kredit terletak pada penerimaan masyarakat dan lalu lintas bisnis untuk memperlancar arus lalu lintas perdagangan dan bisnis. Perjanjian baku pada umumnya mengandung klausula yang tidak setara antara pihak yang mempersiapkan dan pihak lainnya.

Setiap pemberian kredit harus dituangkan dalam perjanjian kredit secara tertulis. Bentuk dan formatnya diserahkan oleh Bank Indonesia kepada masing-masing bank untuk menetapkannya, namun sekurang-kurangnya harus memperhatikan hal-hal sebagai berikut:

1. Memenuhi keabsahan dan persyaratan hukum yang dapat melindungi kepentingan bank;

2. Memuat jumlah, jangka waktu, tata cara pembayaran kembali kredit serta persyaratan-persyaratan kredit 
Marsidah, Bentuk Klausula-Kalusula Baku dalam Perjanjian Kredit Bank, Halaman 285-302

lainnya sebagaimana ditetapkan dalam keputusan persetujuan kredit dimaksud. ${ }^{17}$

3. Perjanjian kredit bank minimal harus memuat klausula yang berhubungan dengan ketentuan mengenai fasilitas kredit yang diberikan, diantaranya tentang jumlah maksimum kredit, jangka waktu kredit, tujuan kredit, bentuk kredit dan batas ijin tarik.

4. Suku bunga dan biaya-biaya yang timbul sehubungan dengan pemberian kredit, diantaranya bea materai, provisi/commitment fee dan denda kelebihan tarik.

5. Kuasa bank untuk melakukan pembebananatas rekening giro dan/atau rekening kredit penerima kredit untuk suku bunga denda kelebihan tarik dan bunga tunggakan serta segala macam biaya yang timbul karena dan untuk pelaksanaan hal-hal yang ditentukan yang menjadi beban penerima kredit.

6. Representation dan warranties, yaitu pernyataan dari penerima kredit atas pembebanan dan segala

17 Rachmadi Usman, Aspek-Aspek Hukum Perbankan di Indonesia, Jakarta: PT. Gramedia Pustaka Utama, 2007, hlm. 267 harta kekayaan penerima kredit menjadi jaminan pelunasan kredit.

7. Condition precedent, yaitu syarat-syarat tangguh yang harus dahulu oleh penerima kredit agar dapat menarik kredit untuk pertama kalinya.

8. Agunan kredit dan asuransi barang-barang agunan.

9. Affirmative dan negative covenants, yaitu kewajiban-kewajiban dan pembatalan tindakan penerima kredit selama masih berlakunya perjanjian kredit.

10. Tindakan-tindakan bank dalam rangka pengawasan dan penyelamatan kredit.

11. Events of default/wanprestasi/cidera janji/trigger clausel openbaar clause, yaitu tindakan-tindakan bank sewaktu-waktu dapat mengakhiri perjanjian kredit dan untuk seketika akan menagih semua uang beserta bunga dan biaya lainnya yang timbul.

12. Pilihan domisili/forum/hukum apabila terjadi pertikaian di dalam penyelesaian kredit antara bank dan nasabah penerima kredit. 
Marsidah, Bentuk Klausula-Kalusula Baku dalam Perjanjian Kredit Bank, Halaman 285-302

13. Ketentuan mulai berlakunya bank, pihak bank berada dalam posisi perjanjian kredit dan yang kuat, tetapi sebaliknya pada saat penandatanganan perjanjian kredit.

Menurut Sutan Remy Sjahdeini yang dikutip oleh Rachmadi Usman, ada beberapa klausula dalam perjanjian kredit yang secara tidak wajar dan sangat memberatkan debitur, antara lain :

1. Kewenangan bank untuk sewaktu-waktu tanpa alasan apapun dan tanpa pemberitahuan sebelumnya secara sepihak menghentikan ijin tarik kredit.

2. Kewenangan bank untuk secara sepihak menentukan harga jual dari barang agunan dalam hal dilakukan penjualan barang agunan karena kredit nasabah debitur macet.

3. Kewenangan bank secara sepihak untuk tunduk kepada segala petunjuk dan peraturan bank yang telah ada dan yang masih akan ditetapkan kemudian oleh bank.

Persiapan klausula-klausula yang demikian adalah upaya bank untuk menerapkan prinsip kehati-hatian dalam pemberian kredit. Bank tidak ingin mengalami kerugian yang disebabkan debitur yang tidak mampu untuk melunasi hutangnya. Walaupun pada saat penandatanganan perjanjian kredit pelaksanaan perjanjian kredit perbankan, maka bank menjadi pihak yang lemah, karena adanya kemungkinan suatu sebab pengembalian ataupun pelunasan kreditnya mengalami kemacetan.

Susunan sebuah perjanjian kredit bank pada umumnya meliputi:

1. Judul

Dunia perbankan masih belum terdapat kesepakatan tentang judul atau penamaan perjanjian kredit bank ini.

\section{Komparisi}

Komparisi menjelaskan sejelasnya tentang identitas, dasar hukum, dan kedudukan subjek hukum perjanjian kredit bank. Sebuah perjanjian kredit bank akan dianggap sah bila ditandatangani oleh subjek hukum yang berwenang untuk melakukan perbuatan hukum yang demikian itu.

3. Substansi

Sebuah perjanjian kredit bank berisikan klausula-klausula yang merupakan ketentuan dan syarat pemberian kredit seperti, maksimal kredit, bunga dan denda, jangka waktu kredit, cara pembayaran kembali dan lain-lain. 
Marsidah, Bentuk Klausula-Kalusula Baku dalam Perjanjian Kredit Bank, Halaman 285-302

\section{PENUTUP}

Bentuk-bentuk klausula-klausula baku dalam perjanjian kredit bank meliputi fasilitas kredit, suku bunga, kuasa bank, jaminan pelunasan bank, kredit precedent, agunan kredit, affirmative dan negative covenant, tindakan bank dalam penyelamatan kredit, event of default/wanprestasi, pilihan hukum, mulai berlakunya perjanjian kredit. Pihak bank diharapkan dalam membuat klausula baku supaya tidak memberatkan nasabah, sehingga prinsip keseimbangan dalam suatu perjanjian dapat tercapai.

\section{DAFTAR PUSTAKA}

\section{A. Buku-Buku}

Abdurrachman, Ensiklopedia Ekonomi Keuangan Perdagangan, Jakarta: Pradnya Paramita, 1991.

Ade Arthesa dan Edia Handiman, Bank dan Lembaga Keuangan Bukan Bank, Jakarta: PT. Indeks, 2006.

Gatot Supramono, Perbankan dan Masalah Kredit: Suatu Tinjauan Yuridis, Djambatan, Jakarta: Rineka Cipta, 2009.
Ismail, Manajemen Perbankan, Jakarta: Kencana, 2011.

Mariam Darus Badrulzaman, Perjanjian Kredit Bank, Bandung: Alumni, 1996.

Mgs. Edy Putra The' Aman, Kredit Perbankan Suatu Tinjauan Yuridis, Yogyakarta: Liberty, 2008.

Muhammad Djumhana, Hukum Perbankan di Indonesia, Bandung: PT. Citra Aditya Bakti, 2006

Permadi Gandapradja, Dasar dan Prinsip Pengawasan Bank, Jakarta: PT. Gramedia Pustaka Utama, 2004. Rachmadi Usman, Aspek-Aspek Hukum Perbankan di Indonesia, Jakarta: PT. Gramedia Pustaka Utama, 2007. Rachmat Firdaus dan Maya Ariyanti, Manajemen Perkreditan Bank Umum, Jakarta: Alfabeta, 2011.

Remy Sjahdeini, Perbankan Islam dan Kedudukannya Dalam Tata Hukum Perbankan Indonesia, Jakarta: PT. Pustaka Utama Grafity, 1999.

Sri Soedewi Masjachan, Hukum Jaminan di Indonesia Pokok-Pokok Hukum Jaminan dan Jaminan Perorangan, Yogyakarta: Liberty, 1980.

Thomas Suyatno, Dasar-Dasar Perkreditan, Jakarta: Gramedia, 1990. 
Marsidah, Bentuk Klausula-Kalusula Baku dalam Perjanjian Kredit Bank, Halaman 285-302

B. Peraturan Perundangan-undangan Undang-Undang Nomor 10 Tahun 1998

Undang-Undang Dasar 1945.

Kitab Undang-Undang Hukum Perdata (Burgerlijk Wetboek).

Kitab Undang-Undang Hukum Dagang (Wetboek van Koophandels).
Pasal 1 Butir 11 Tentang Perubahan atas Undang-Undang Nomor 7 Tahun 1992 Tentang Perbankan Undang-Undang Nomor 8 Tahun 1999 Tentang Perlindungan Konsumen 